\title{
RECREATION OF ORAL POETIC GENRES IN SELECTED YORỦBÁ HOME-VIDEO FILMS
}

\author{
Abidemi Bolarinwa \\ University of Ibadan, Nigeria
}

\begin{abstract}
The Yorùbá film as audio-visual literature is thought of as one of the most educative components building society. "Modernization" and responses to global change brought about the Yorùbá films which are an offshoot of the Yorùbá Travelling Theatre Movement. The indigenous theatre practitioners who are versatile in practicing the oral poetic genre and have successfully emerged as producers, directors and film-script writers employ and recreate oral poetic genres by adding feelings, beliefs and knowledge they had acquired in the past. This paper attempts a descriptive analysis of five purposively-selected Yorùbá video films by using the sociological approach: Ẹfúnsetán Aníwúrà; Basọ̀run Gáà, Ogun Àgbẹ́kọ̀ya, Ogun İdàhọ̀mì and Ọ̀rànmíyàn; which are replete with instances of ingenious recreations of Yorùbá oral poetic genres. The analysis is conducted with a view to elucidating the attempts of Yorùbá home-video scriptwriters in recreating and reconstructing their experiences. The analyses of the selected Yorùbá home-video films reveal that the Yorùbá home-video script writers make artistic use of Yorùbá oral genres in their films through the creative exploitation of proverbs, songs, chants and mythical allusions. The allusions to myths in the selected films suggest that Yorùbá home-video films share apparent inter-textual links with Yorùbá oral poetry. The study concludes that Yorùbá home-video scriptwriters deploy oral poetic genres in their films as one of the ways in which the artistic experiences of the Yorùbá people can resonate.
\end{abstract}

KEYWORDS: YORÙBÁ VIDEO FILMS, ORAL GENRES, MYTHS, SOCIAL CHANGE, RECREATION

\section{Introduction}

Adédèjì (1971) explains that literary and historical oral traditions are the two types of oral tradition. The literary oral traditions include praise, chants, Ifá divination, songs, proverbs, parables and incantations, while the historical oral tradition consist of narratives based on myths, legends and historical plays such as epic.

Films cut across different fields and languages and have drawn attention of numerous researchers. Some scholars have trodden the path of analyzing films from different perspectives. Ekwuasi (1987) wrote extensively on the emergence of film in Nigeria. Mgbejume's (1989) work is based on the historical development of Nigeria films and the problems facing the film industry. Àlàmú (1991) dwells on the trends in the development of Yorùbá video-films within the first ten years of their existence - 1976-1986. Also, Àlàmú (2002) examines the aesthetics of Yorùbá video films. Adélékè (1995) examined 
audience reception of Yorùbá films in cinema houses. Haynes (2000) focuses on Nigerian Video Films. Ògúnlẹ́yẹ (2003) examines African Video Film Today. Balseiro and Ntongela (2003) examine Film and Film Culture in South Africa. Adésọkàn's approach (2004) is based on the Politics and Aesthetics of Nigerian Video Films. Olújìnmí (2005) dwells on the portrait of the female in Yorùbá video films, while Adágbádá (2005) examines womenfolk in the Yorùbá video-film industry. Armes (2006) works on African Filmmaking North and South of the Sahara. Yusuf (2006) delves into the issue of Adébáyọ Fálétí on screen. Olútúndé's work (2006) is based on a mythological reading of Bámilóyè's Agbára Ńlá and Ìdè Èșù Christian Films. Akínyẹmí (2007) discusses Aesthetics, Transfer and Social Vision in Two Yoruba Video Films while Misikawong (2007) treats Working Practices in Thai Independent Film Production and Distribution. A piece by Adágbádá (2008) is based on Yoruba Texts on The Screen in Africa through the Eye of the Video, while Sèssan (2008) examines African aesthetics in Yorùbá language video films. Adéòtí (2009) discusses Home Video Films and the Democratic Imperative in Contemporary Nigeria while Dovey (2009) examines African Film and Adapting Violence to the Screen. Arúlógun (2009) treats The Role of the Film in Cultural Identity. Yekeen (2009) surveys the use of folklore in Yorùbá films. Adú (2009) highlights the various issues of propaganda and their functions in Yorùbá video-films. Michol's work (2010) is an Introduction to Documentary Films. Mobólájí (2011) looks at parody in selected Yorùbá video films. Sólalú (2014) examines the reflection of vices in Yorùbá films, while Fámúàgún (2015) focuses on culture and value change in selected Yorùbá home videos.

The emergence of video film production, distribution and exhibition in Nigeria was systematic and gradual. The embryonic stage of video film production can be traced back to the theatrical performances of Alárìnjó theatre (Adédèjì, 1981). Thus, Alárìnjó theatre provides the basis for the development of film culture in Nigeria. Since its inception, the home-video film has become an alternative venture for the creative ability of the Yorùbá theatre practitioners. The film industry has progressively projected African cultural heritage to other parts of the world. According to Àlàmú (2010), the untiring efforts of the film producers in promoting the Yorùbá language and culture have encouraged other ethnic nationalities in Nigeria to realize the potential of the medium for promoting their respective languages and cultures.

\section{Theoretical Approach: Sociology of Literature}

Because literature burdens itself with human expression, human experience and human behaviour (Ògúnșínà, 1987), this study employs the sociology of literature, as man is a product of his society. Moreover, literature is part of and a product of society. Literature uses language to explain society. It is used to reflect and retract what might have happened in a particular society at a certain period of time (Dasylva, 1995). The scriptwriter is also a member of the society. In producing films, he/she actualizes and reuses materials that were circulating in society. Barber (1978:7) is of the opinion that, sociology concerns itself with all that happens to human beings as a result of their relation with one another in society. As with all social sciences, it deals with the world of man's experience, man's 
behaviour with regard to his fellow human beings, but its main focus is the larger social entity. The relevance of a sociology of literature to literature even in modern times has also been mentioned in works of critics such as Ogundeji and Fasehun (2016), and Mobolaji (2016) respectively. The sociology of literature therefore is an attempt to understand the interrelationship between literature and society. It postulates that a work of art does not exist in isolation and should not be studied as such. This is because works of art are not independent of their society. Taking a closer look at the films examined here, one can clearly see that it has much that is relevant to the society. Home-video film is a fruit of the society; it cannot be studied in isolation without an understanding of the society in which it was created.

\section{Synopses of the selected films}

This section presents summaries of a number of Yorùbá home-video films selected and arranged for the purpose of fulfilling a complex set of imaginative and theatrical purposes by the scriptwriters. This will aid understanding of the selected films under study.

\section{Basòrun Gáà}

The film, Basòrun Gáà, is a historical reconstruction of the life and times of Gáà, the head of the òyómèsì (the traditional king-makers of the ancient Òyọ́ kingdom) during the tenure of Oba Abíódún Adégoólú as the Aláàfin of Òyọ́. The film centers on the acts and vices of Basòrun Gáà, the head of the king makers. He was a powerful man who played the lead role in the crowning and executions of four installed kings during his reign as the Basòrun and would have done the same to the fifth but for the timely intervention of ààrẹ Oyaabí, the ààrẹ ònà kakañfò (Field Mashal), who fought and overpowered him. He is portrayed as a leader who loves and desires absolute authority? But such authority is denied him on account of the ban on the Osòrun title that they can never be a crowned king. Gáà is vested with power and authority, and he wields it to the detriment of his people. In order to appease the basòrun, the moment king Adégoólú ascends the throne he lavishes Gáà with compliments. The last straw is the killing of Oba Adégoólú's only child, Àgbò̀yín, by Gáà. The king seeks the help of ààrẹ Oyaabí, and with the support of Òyó people, Gáà is conquered and peace returns to Òyọ́.

\section{Efúnșetán Aníwúrà}

The film, Efúnsetán Aníwúrà is a recreation of the history of a woman chief of Ìbàdàn (İyálóde Efúnsetán) during the time of ààre Látòósà. Efúnsetán is portrayed as an economic and political figure who ranks with men in terms of her exploits. These feats won her the admiration of many and also made her an enemy to the head, ààre Látòósà, who sees her as a threat, but lacks strong evidence to justify attacking her. Éfúnsetán is a loving mother and mistress who showers love on all and sundry. However, her actions change for the worse when she loses her only daughter who dies during childbirth; she killed Ògúnjìmí, the palm fruit tapper, and subjects her slaves to merciless beating and starvation. She also goes to the extent of placing a ban on childbirth in her domain. Any 
defiance to such instruction sees the death of the subject and whoever is involved. All pleas to spare her slaves fall on deaf ears, and necessary action is thus taken to curtail future acts. War is unleashed on her, and she commits suicide in her abode, seeing that she has been over-powered, after confronting the ààre himself.

\section{Ogun İdàhòmì}

The film, Ogun İdàòmì is the historical recreation of how Òtà people at several times in the $18^{\text {th }}$ century prevented the traditional Ėgbá people from crossing their land into the old Lagos province where there was a very large presence of white men who brought commercialization and new technology into the old Lagos colony. In their quest to transact business with the white men in Lagos the Ėgbá people were attacked at Òtà border. When the news reaches Sódẹkẹ́, the Oba of Ėgbáland orders Akóódú one of his powerful warriors to follow Ėgbá traders to Lagos; he overpowers the Òtà warriors, and they are able to transact their businesses. The role of a traitor that Àkànbíyééku plays by revealing the Ò̀tà plan to the Ėgbá people costs him his life, - his elder brother vows to avenge his death. The killing of Jẹunsínú an Ègbá man who refuses the order of Sódẹkẹ́ concerning the abolition of the slave trade, and the beheading of an İdàhọmì slave trader to Ògún shrine, lead to war between Ėgbá and İdàhọ̀mì people. The İdàhò̀mì people seek assistance from Òtà people so that together they can conquer the Ėgbá people, but the invitation is not honored because they are both Odùduwà's descendants. In the end, Ėgbá people conqure the İdàhọmì people because Sódẹkẹ́ has given himself as propitiation to the gods. Sódẹké dies in his bed after the war and he is greatly mourned.

\section{Òràmíyàn}

Òrànmíyàn is the recreation of the life and achievements of the last born Yorùbá progenitor, Odùduwà, known as Òrànmíyàn. Òrànmíyàn was king in Ilé-Ifẹ̀ until he left for Uselu to also be their king. Obalùfọ̀n reigned in Ifẹ̀ as their king after Òrànmíyàn's departure. After Obalùfọ̀n's demise his son, Aláyémọrẹ, became king. At Uselu, Òrànmíyàn married princess Erínwindè, but no sooner had Òrànmíyàn ascended the throne, the chiefs began to find fault in his ways of administering justice. Erínwindè and the chiefs conspired against Òrànmíyàn, and he left the throne in annoyance after casting a spell on them that no other person will occupy the throne except his son. He also renamed Uselu land "Ilè Ìbínú" (Land of Annoyance) which was later changed to Benin land. Òrànmíyàn, in his journey, sojourned in Tápàland, and helped them defeat the İbàrìá warriors. In appreciation, the king of Tápàland gave his daughter, Torosí, to Òrànmíyàn as his wife, and she gave birth to Șàngó and Àjàká. Òrànmíyàn later established another town known as Ò̀yọ́, and after many years of sojourn, he returned to Ilé-Ifẹ̀ with his family members amid pomp and pageantry. Òrànmíyàn reigned for many years in Ilé-Ifè̀, and his children also became kings in their respective domains. At the end, Òrànmíyàn disappeares and leaves his staff as a remembrance.

\section{Ogun Àgbẹ́kòyà}


The film, Ogun Àgbékòyà, is a historical recreation of the unrest between the farmers and the government in Ìbàdàn. The İwàloyè people were major farmers who dealt in cocoa. The ridiculous cuts in the price of a tonne of cocoa from ten kobo to two and half kobo and increases in taxes did not go down well with the farmers who could no longer meet their financial obligations. The farmer, through their village head presented their complaints, but to no avail. The youths also complained about some buildings that had been demolished but the government's representatives turned a deaf ear. The farmers made Amúbíeyá their leader, and when government representatives attacked the people of İwàloyè town at the worship centre, on the market place and on their farms, the farmers and their leader, Amúbíeyá, retaliated by attacking the government's representatives and the police. They fought and prevailed through diabolical means. The premier of the region made a timely intervention and organized peaceful negotiations with the farmers. However, the police way-laid the farmers and attacked many of them. The farmers broke into the jail at night and set all the prisoners free. Amúbíeyá was declared wanted by the police for jail break, but with the help of Margaret, a disguised police officer who professed to be in love with him, the police was able to capture Amúbíẹá.

\section{Recreation of Oral Poetic Genre in Selected Yorùbá Video Films}

Yorùbá home-video scriptwriters appropriate the resources of their oral traditions in individual and creative ways, and forge the materials into varied, new and interesting forms. The scriptwriters borrow from the rich African verbal art forms to create new visions of life and new poetic idioms with remarkable originality. The scriptwriters' employment of the rich Yorùbá oral genres makes the films unique and interesting. The oral poetic genres that are analysed in the selected Yorùbá video films are proverbs, praise poetry, songs and myths.

\section{Proverbs}

Proverbs are a universal phenomenon that have been highly valued from ancient times to the modern age. Proverbs are a rich source of imagery and succinct expression, encapsulating abstract ideas and allusive wordings, usually in metaphorical forms. As in many parts of the world, the Yorùbá hold proverbs in high esteem because they are regarded as the wisdom lore of the society. Proverbs are considered to be traditional and to have originated from the observation of natural phenomena and human relations, and old people are regarded as a repository of proverbs. The scriptwriters of the selected Yorùbá homevideo films use proverbs to express an essential idea. They are not usually subjected to a rendition in their original forms. Rather they are modified and adapted according to the demand of rhythm and beat.

An instance of the modification of proverbs is to be found in the film, Orànmíyàn, when Àjàká is reporting Șàngó's absence in Òyọ́ to their mother, and she tried to defend him; he responded in a brave tone, and Torosí says:

Omo àjànàkú kì i yàrá

Omo tẹkùn bá bi 
Ohùn akin ní ń be lẹ́nu won

An elephant's child cannot be sluggish

A child born of a leopard

Always have the voice of the brave

The original form of the proverb is:

Omo àjànàkú ki i yàrá

Omo tí Eyá bá bi ní i jo

An elephant's child cannot be sluggish

A child given birth to by Eyá will always resemble Eyá

Though a few words have been added to the proverb, the original meaning is retained. What Torosí is saying in essence is that Àjàká's father, Òrúnmilà, is a very courageous man. Hence, Àjàká is also expected to take after his father.

Another example of the recreation of proverbs is seen in Olátẹjú's speech in Ogun İdàhòmi when Àkànbíyéékú visits her for the first time after the attack. She says:

Ata ki i sòrẹ ojú

Omi kì i sòré iná

Pepper is not friendly to eyes

Water is not friendly to fire

The original way of rendering the proverb is:

Iná àti ètù kì i sọré

Fire and gun powder are not friends

In the original proverb, there is emphasis on the danger of the interaction or contact between iná "fire" and ẹtù "gunpowder" a mixture that can wreak havoc. Also, such danger is further illustrated in the modification where ata "pepper" versus ojú "eyes" and omi "water" versus iná "fire" cannot mutually interact. The danger of such interaction brings about the assertion employed in Yoruba invocation with the saying thatojọ́ tí atá bá bọ sójú ní i ba ewà ojú jẹ "the beauty of the eyes is affected the day pepper drops on the eyes”. What Olátéjú is telling Àkànbíyéékú in essence is that both of them are not friends, therefore, his visit to her house is suspicious and questionable.

Also, in Ogun İdàhọmì, when Akóódú is given instructions to Ėgbá traders, he warns them with this proverb:

E má jó kojá àgèrè

E má tasè kojá ijó 
Don't dance beyond àgè̀rẹ̀ drum

Don't raise your leg more than the dance

The normal way of rendering the proverb is:

E máse tasè àgèrè

Don’t go beyond your boundary

Dancing beyond the drum or moving faster than the beat could bring confusion, while dancing beyond one's reach or limit can lead to calamity. As a result, Akóódú uses the proverb to forewarn the Ėgbá traders to behave themselves because they are journeying along the Òtà border, and such an act can lead to war with the revered Ọtà warriors. The artistic recreation of the proverb by Akóódú does not change the meaning of the proverb in its original form but adds to the aesthetic splendour of the proverb.

Another instance of the recreation of proverbs is seen in the film Basòrun Gáà. After the execution of the king, Májècógbé, the next in line to the throne, Débíìyí, decides to flee because of his fear of Gáà, a callous man who develops an interest in killing and enthroning one king after the other. When the people appeal to him not to run away, he says:

Àgbókù àtòrì tí a fi na ìyálé

Tólómoge bá wolé oko tán

Ó lè gbó mó olómoge lára

The remnant of the whip that was used in beating the senior wife

When the newly wedded wife enters her husband's house

It can also be used to beat the junior wife

The original form of rendering the proverb is:

Òpá tí a fi na iyáálé

Ò wà lájà fún ìyàwó

The whip used to beat the senior wife

Is on the roof for the younger wife

Débíiyí is afraid of death; he is now telling his people that he does not want to suffer the same fate of the other kings in the hand of Basọrun Gáà. The character replaces Òpá with Àgbókù àtòrì and ìàwó with olómoge to suit contemporary language usage as at the time of production. While such whip is said to be on the ceiling in the original proverb, it is potrayed to be within reach in the recreated proverb. Though the proverb is recreated by Débíiyí, the meaning of the proverb in its original form is retained.

When Gáà in the film Basòrun Gáà is addressing the chiefs on the need to install another king so that the town can have a leader, he says:

Bílùu kò dùn 
Kò sómo tálákà tí yóò ròde ẹmu

When the town is not peaceful

The son of the poor cannot go for a drink

The original form of the proverb before it was recreated is:

Bóò̀dè ò dùn

Bì igbé ni ilú ri

When the home is not peaceful

The town will be like dung

The proverbs illustrate the importance of good governance and peace in a community. Peace breeds abundance, growth, good commerce and an avenue for trade. Hence, the recreated proverb emphasises the adverse effect of having no peace on the community. This modification is made possible by replacing ọọdẹ with ìlú and bi igbẹ ni ilú ń rí with kò sọmo tálákà tí yóò ròde ẹmu to the notion of pleasure. Gáà wants another king to be enthroned so that peace can return to Òyó town and for people to go about their normal business without any disturbance.

After the installation of King Abióndún Adégoólú as the new king in Òyọ in Basòrun Gáà; he fears that he may be killed by Gáà suffering the same fate of his predecessors. To avoid this, Adégoólú makes known his intention to run away to İyá-Ilé Orí, and she responds thus:

Omooba tí ń bèrù jèjẹ

Irú won ki i róyè ilé baba won jẹ

A prince that is afraid

Such will never claim his family's title

The above proverb is the recreation of the original form that goes thus:

Nò lè kú kan

Ki í joyè ilé baba rè

I don't want to die

Will never claim his family's title

The proverb is modified through the substitution of the first person pronoun ' $N$ 'to 'the prince' and 'dying' with 'fear/cowardice'. İyá-Ilé Orímakes the statement more direct to Adegoolu to address his overwhelmimg situation and to bolster him so that he wont 'bow to cowardice and run away like other prince. This is also a silent allusion to Debiyi, a prince, who should have been crowned king after the death of Majeogbe but ran away 
with his wife and children. İyá-Ilé Orí encourages Adégoólú to shun fear and be courageous because fear will worsen the situation and that he should not run away. Rather, he should wait and think of how to overcome his fear, Gáà.

While grinding pepper and working in İyálóde Efúnsetán's backyard in the Yorùbá video film, Efúnsetán Aníwúrà, one of her slaves, Adétutù laments:

\section{Òsisé wà lóòrùn}

Eni tí yóò jẹ wà níbòji

Workers are under the sun

The person that will eat it is inthe shade

The original form of the proverb is:

Òsisé wà lóò̀ùn

Náwónáwó wà níbòji

Workers are under the sun

The person that will spend the money is in the shade

Adétùtù is lamenting her sorry state, that she is only grinding the pepper that she will not taste it. She is bitter about the way they have being overused by their master, İyálóde Ẹfúnsetán. There is a modification through substituting Eni tí yóò jẹ for Náwónáwó since it applies more to Adetutu's prevailing situation in the film. The person performing the task does not enjoy her labour since she has the sole purpose of pleasing the Lord of the house. The proverb retains its actual meaning despite the recreation.

Also, in Ogun Àgbẹ́kọ̀yà, when the farmers contact Àwíyé, a lawyer, to sue the government on their behalf and he advises them to exercise patience, they leave his office in annoyance and threaten fire and brimstone. The lawyer replies thus:

A ki i fàijinná òlè fitara méwé

We cannot transfer the pain of uncooked ọ̀lè to leaf

The original form of the proverb is:

\section{A ki i fikanraàità májé}

We cannot transfer the pain of poor salesto Ajé

Though the scriptwriter recreates the proverb, it does not change the original meaning of the proverb, and the lawyer is simply telling the farmers that they cannot shift the blame for what they are suffering at the hands of government to him, because he is not the architect of their misfortune. The modification is made possible through the lexical matchings; Fàijinná òlè and fikanra àità then méwé and májé to suggest same meaning.

When the farmers employ diabolical means in dealing with the police officers and many 
of them are maimed, two police officers who are afraid of the farmers approach them for succor. One of the farmers, out of annoyance, responds thus:

Bí won ó bá gbàwìn ẹbà, ni wớn gbọmo ẹlẹbà jó

Bí wớn bá yó tán, wớn á dọo ẹni gbogbo

It is when they want to buy è̀bà on credit

that they romance the è̀bà seller,

the moment they are satisfied, they lord themselves

over everybody

The original form of the proverb goes thus:

Bí èdá ó bá gbàwì èbà, ni wớn sojú àánú

Bí wớn bá yó tán, wọ́n á doko olúwa won

It is when human wants to buy èbà on credit

that they will be sober. The moment they are

satisfied, they lord themselves over their boss

The farmers know that it is because of the fact that the policemen's lives are in danger that they are now asking them for protection. The farmers are aware of the fact that the policemen are traitors who cannot be trusted; therefore, the policemen are killed. The original form of the proverb and the one that the scriptwriter recreates has the same meaning; the recreation of the proverb does not alter its original meaning. In the first line, wọ́n is substituted with ẹdá to reiterate that the habit is common among human beings while ni wón gbọmo ẹlébà jó, which replaces ni wọ́n sojú àánú makes emphasis on being more familiar or coming to the level of that person. The modification adds aesthetics to the proverb. The recreation and adaptation of proverbs by the scriptwriters in the selected Yorùbá home- video films at times take the form of adding a few words or of contrasting the proverb words but they still retain the essential image necessary for its identification.

\section{Praise Poetry (Oríkì)}

Praise poetry is a genre of Yorùbá oral poetry that could be described as attributions or appellations. In the wealth of Yorùbá oral literature, they are probably the best known of all Yorùbá peotic forms (Barber 1991). According to Lásebìkan (1958:32), as cited by Olátúnjí (1984), Oríkì can tell where a person originates from, how powerful his ancestors were, how wealthy they were and all their noble deeds. The importance of Oríkì to Yorùbá society cannot be over-emphasized. Olátúnjí (1984:67) opines that:

It is traditionally believed that correct performance of Oríkì in honour of a progenitor gladdens the progenitor in the world of spirit and induces him to shower blessings on his offsprings on earth. The reciting of appropriate oríkì in honour of ancestor of a particular family causes members of that family who hear the performance to feel very proud of their pedigree, they also feel exceedingly home sick. 
Oríkì encapsulates the past and bring is it into the present, where its exercise is a continual pull.

Oríkì is one of the principal discursive media through which much is known about the characteristics of the person or things that are being praised, and people apprehend history, culture, customs, norms, society and the spiritual world. Oríkì makes people realize the gain of valor and sacrifice for one's mother land. Anyone who performs heroically to defend a community by warding off vandals deserves community commendation in the form of praise poetry. The Ifẹ̀ people do not fail to praise Òràmíyàn in the film Òrànmíyàn as the founder of their community and also as defenders of their territorial integrity. The Ifẹ̀ people praise Òrànmíyàn thus:

Òrànmíyàn bá iná jà ó dá iná

Òrànmíyàn bá ò̀rùn jà ó dá ò̀rùn

Òrànmíyàn àbíkèyìn Oòduà

Baba Ajàká

Baba Șàngó

Ana Eléñpe

Alásẹ ilè Oòduà pátá

Jagunjagun pàtàkì

Òrànmíyàn fight and conquer fire

Òrànmíyàn fight and conquer sun

Òrànmíyàn the last born of Oòduà

Father of Àjàká

Father of Șàngó

In-law to Eléǹpe

The overall controller of Oòduà land

An eminent warrior

As the Ifẹ̀ people eulogize Ò̀rànmíyàn with the above Oríkì, it evokes a feeling of solidarity with his blood relations, of pride in his ancestry. Also allusions are made to his origin, events and actions that are important, and this certainly has stimulating effects on Òrànmíyàn and spurs him to greater action.

In the king's palace, the bard usually recounts the history or activities of the king's predecessors and enjoins him to uphold the customs, traditions and ruling principles of the royal house, all of which contribute to the maintenance and stability of his authority. In addition, they praise the king and the chief for material and monetary gains. In the film, Basòrun Gáà, the bard praises Gáà thus:

Gáà jírire lónìi o

Bóbá wolúgbón kó má jiire

Bóbá warèsà kó má jíire

Bí Gáà bá ti jíire 
Abùse bùse

Basòrun àgbà, bó o bá ti jíire

Abùse bùse

Gáà you are hail and hearty today

If it pleases Olúgbón let him wake up and be healthy

If it pleases Arèsà let him wake up and be healthy

So far the Gáà is hale and hearty

We are pleased

Basọrun the highly referred one,

so far you are hale and hearty

We are pleased

The original oriki is:

Emó jíire lópòó ilé

Afèrèmọjo jíire nísà ilè

Báwa bá ti jíire, àbùșe-bùșe

The rabbit wakes up hale and hearty

The small rat wakes up hale and hearty in its hole

So far we are hale and hearty, we are pleased.

The proverb is modified from being personal praise to delivering showers of extravagant praises on the revered Gaa. This also points at the role and lifestyle of Gaa and his family whose lavish lifestyle and thirst for power is to the detriment of their followers. The praise above, rendered by the bard induces Basọrun, who was listening from his bedroom, to send cash and material gifts to the bard as a form of compensation.

One of the features of Oríkì which traces the origin of a lineage or a family and commemorates personalities, events and actions that people consider important are brought to bear when Sàmù praises Oyaabí thus in the film, Basòrun Gáà:

Èsó kì gb'ofà léyìn

Gbangba iwájú ni wón fii gba tiwon

Èsó tó wù kó gb ơfà léyìn

A jẹ wi pé șe ló sá gun

The Ėsọ́ never received arrow shots in the back

Any Ėsọ́ that received arrow shot in the back

Definitely absconded from the battle

The above oríkì reveals the military prowess of Oyaabí progenitors. They are known for their bravery and dexterity in battle. The oríkì above is used in eulogizing Oyaabí and serves as a spur for him to combat Basọrun Gáà.

Oríkì is also one of the principal discursive media through which much is known about 
the characteristics of the person or thing that is being praised. Akínkúnmi in the film Basọrun Gáà reveals the evil and deadly nature of Gáà when Àgbònyín disclosed to him her father's intention of betrothed her to Gáà. He exclaims thus:

Iba tí i bolé tí i boko

Eni tí ikú i rán pa ni

Èrù jèjè tí i bomo àdúgbò

Iba that is capable of taking over the home and farm

The messenger that death sends to kill people

The fearful one that terrifies the children in the neighborhood

Another variance of such oriki is;

Iba tí ì gbalé, tí i gboko

Ikú tí i pomo tí baba ò gbodọ gbin

Arùn tí i sọmo màmá ò gbodọ sọrọ

Èrùjẹjẹ ní gbogbo ilẹkílẹ

Iba that is capable of taking over the home and farm

The death which kills a child while the father remains silent

The disease which affects a child and the mother must keep shut

The one revered in all towns

As known in oriki, renditions differ while the leitmotif remains the same. The two praises are from different people who express the same thoughts in different ways and at different times. The evil and deadly nature of Gáà is obvious in the above praise poetry. People fear Gáà because of the roles he played in the crowning and execution of four kings during his reign as Basòrun. Despite the fact that people, even other king makers, know about Gaa's mischiefs, no one is bold or strong enough to confront him. Only the bards could do that in a subtle way since they enjoy immunity in their art. Hence, Gáà is aptly described asdeath itself, a murderer and disease who ravages people beyond repair.

All the praise poems used by the scriptwriters eulogize and reveal the characteristics of the subject of oríkì, and with this the scriptwriters employ oríkì as one of the Yorùbá oral poetic genres to drive home their point about the characters being praised.

\section{Songs}

Song is a universal phenomenon, and a major medium for exhibiting one's thoughts. In Africa, song is a sub-set of oral poetry, and among the Yorùbá, it is a veritable genre of oral literature. Olúkojú (1978:89) submits that 'orin' is the generic term for all types of songs. Songs, like music, are synonymous with all human activities. Songs are products of the modulating effects of the vocal chord which produces sounds that vary in tunes, tones and pitch. Song can be produced and rendered individually or communally. In Africa, songs "are known to influence people with regard to events" (Finnegan, 1977). Songs carry the 
pulse of individual or communal feelings because they are based on events in individual or communal life. The scriptwriters of selected Yorùbá video films adapt and re-create various Yorùbá songs to depict different situations practices and as well as different themes.

In the film, Basòrun Gáà, the mean and cruel king, Májẹógbé kills his father-in law, Ìlọ̀í, the bàtá drummer, at Jàbàtá just because he could not take the joke that his wife throws at him. Májèógbé's decision to kill İlọ̀rí does not go down well with the Òyọ́ people and on the order of Gáà and the Òyọ́mèsì, Májẹógbé is executed and the people sing thus:

Alágbára ayé e sayé re

Alágbára ayé e sayé re

Eniyàn șe pèlé ilè ń yò

Ojó tó ò wèyin tó ò ní rénikan mó

Alágbará ayé e sayé re

The powerful one be careful

The powerful one be careful

People thread softly the ground is slippery

The day you will look back and see no one

The powerful one be careful

Another variance of the song which is not used in the film also points attention to being careful while in power. It says:

Báyé bá ń yẹ ó

O rọașe

Bó o bá wà nípò

Má mà babè jẹ

Enìyàn ló lònì

Elédùmarè ló lọla

When fortune smiles at you

Be careful

When you are up there

Do not destroy the place

Human beings only know about today

God knows tomorrow

The scriptwriter is more direct based on the prevailing situation in the film. This is effective because songs or choruses give additional information in the play and it intimates to the viewers the possible outcome of an action. The song is a warning to the powerful to be cautious so that they do not misuse their power as did king Májèógbé. The song is reinforcing the importance of being cautious when one is powerful. The song therefore is educating and enlightening the people.

During the installation of the new Aláàfin Abíódún Adégoólú, songs were rendered to honour the king and entertain the people that witnessed the installation: 
Bérín jẹ erin a pagbo o

Bérín jẹ erin a pagbo

Adégoólú dide o foba hàn

Bérín jẹ erin a pagbo

Àyànfẹ ará Òyó, bàbá $O$ ò sì fọba hàn

Bérín je erin a pagbo

When the elephant eats the elephant makes a circle

When the elephant eats the elephant makes a circle

Adégoólú arise and show your majesty

The chosen king of the Òyó people, father won't you

show your majesty,

When the elephant eats the elephant makes a circle

From the above song, the people show their acceptance of the choice of the newly installed king, and they also beckon to him, to rise and display his royal honour and majesty. This song is a modification of "ṣẹ̀kẹ̀rẹ lọba ń jó" where such song reveals the kind of music the Aláàfin of Oyo dances to. The song is, therefore, reused to call on the king to dispaly his royalty and elegance in the presence of his people with his dancing steps. Also, the song entertained the audience, and one is able to deduce that the new king and his subjects are in a joyous mood.

In the film Efúnsetán Aníwúrà the only child of İyálóde Ẹfúnsetán died together with her baby at childbirth. This was a terrible blow to Iyálóde and her households. The people sing as they commiserate with her:

Oníyáre ò, eye ure ibèdú o eye

Oníyáre ò , ẹyẹ ure ìbèdú o ẹyẹ

Bo bá délé ko kílé

Eyẹ ure İbèdú o eye

Bo bá dónà ko kónà

Eyẹ ure ibèdú o eye

Ó dení òhà

Ó dèjí òha

Ó dèta òha

Eyẹ ure İbèdú o eye

Oníyare, the bird of İbè̀dú

Oníyare the bird of Ìbèdú

Greet them when you get home

Greet them on your way home

At the count of one

At the count of two

At the count of three

Oníyare, the bird of İbèdú 
The above song is a type of dirge that is adapted by the scriptwriter to mourn the passing away of İyálóde's only child. The song reiterates the ambiguity of life, its sweetness and bitterness and the Yorùbá belief that we are sojourners on earth and heaven is our final abode.

The Yorùbá people love singing and this permeates every sphere of their lives. To curb the excesses of İyálóde Éfúnsetán, Ààrẹ Látòósà and the Ìbàdàn chiefs declare war against Efúnsetán. Below is one of the war songs rendered by the people as they are fast approaching İyálóde's residence:

E lòrò náà kó yé wa

E lòrò náà kó yé wa

Bígún ló loko $n i$

Bí tàkúté ni

E lòrò náà kó yé wa

Make it clear to us

Make it clear to us

If the land belongs to the vulture

If the land belongs to the trap

Make it clear to us

Another variance of the song is:

E lòrò náà kó yé wa

E lòrò náà kó yé wa

Bíkún ló loko ni

Bí tàkúté ni

E lơrò náà kó yé wa

Make it clear to us

Make it clear to us

If the land belongs to the squirrel

If the land belongs to the trap

Make it clear to us 
There is a small modification in the song used in the film with regard to the noun Igún which is Ikun in the common usage. This is strange as vultures are not usually trapped or killed in Yorubaland because they are seen as sacred birds and traps are not usually used. This is just to illustrate the arduous task. The above song is a war song rendered to incite trouble and also insult and challenge İyálóde Ẹfúnsetán's authority; this leads to a public display of might and strength by İyálóde Ėfúnsetán and Ààrẹ Látòósà. To avoid public assault and disgrace, İyálóde commits suicide.

Olúfẹ̀ festival is a traditional festival that is celebrated annually among the Ifẹ̀ people. In the film, Orànmíyàn, the Ifẹ̀ people sing thus during the festival:

Odún Olúfẹ làn șe

Aboyún a bi wẹré

Àgàn á towó bosùn

Kábíyèsí oba wa

Òràmníyàn oba wa

Olúgbón șe é ayé rójú

Arèsà șe e ayé róju

Adé a pé lórí

Bàtà a' pé lésè

Odún olúfẹ là ń șe

We are celebrating Olúfẹ̀'s festival

The pregnant women will deliver safely

The barren will dip their hand in Osùn

Your highness our king

Òrànmíyàn our king

Olúgbọ́n's reign was peaceful

Àrè̀sà's reign was peaceful

You will wear the crown for long

You will wear the royal shoes for long

We are celebrating Olúfẹ̀'s festival

The Ifẹ people through the above song are showing their happiness at witnessing another celebration of the festival and at the same time proclaiming to the people that it is time for another wonderful experience. The song no doubt establishes a joyous mood and lifts the morale of the people. It is also a supplicatory song for the peaceful and long-lasting reign of their king, Òrànmíyàn, and the well-being of the entire Ifè̀ people. The scriptwriter makes allusions to the reign of Olúgbọ́n and Arè̀sà who were great kings in Yorùbáland. These allusions show the scriptwriter's interest in his localized audience, and it enhances great sense of belonging and credibility.

The scriptwriter of the film Ogun Àgbẹ́kọyà adapts many Yorùbá protest and war songs to reinforce the themes of the film which include political tension and chaotic situations. 
Owó orí ò șé é san

Owó orí ò șé é san

Kòkó ó tà

Àgbàdo ò gbówó lórí

Owó orí ò șé é san

It is difficult to pay tax

It is difficult to pay tax

Cocoa is no longer profitable

The price of maize is going down

It is difficult to pay tax

The above is a protest song rendered by the farmer's association to make known their grievances about the cut in the price of cocoa and the intolerable increases in taxes. The structure and form of the song is synonymous to that of Dágunró ò șe é jẹ... "Dagunro cannot be eaten..." The contents differ but the drumbeats and other emotions put into the songs as protest are the same. This reveals the artistic way poets, scriptwriters and the Yoruba people string words or statements together with similar rhythmic patterns for aesthetic effect. The farmers express their hatred and hostility towards the government through the song.

Below is another war song rendered by the same farmer's association in Ogun Àgbẹ́kọyà film:

Òkú akódà ní ó kun

Òkú akódà ní ó kun

Kòtò gìrìò tí ń be nílè yií

Òkú akódà ní ó kun

The police corpse will fill it

The police corpse will fill it

The dungeon that is in this town

The police corpse will fill it

The above song rendered by the farmers is for incitement of trouble, to challenge and insult the police. It is also a confrontational song from the farmer's association that is meant to scare and intimidate the police force. The farmers and the police engage in battle, and the farmers association prevails through diabolical means.

The Premier of the region makes a swift intervention to resolve the crisis between the farmers and the police force by organizing a peace-talk with the farmers. After the peacetalk, the farmers sing thus:

Awólówò baba Láyínká

Ò ó se bó o ti wí

Omo àlè n ii sòrò̀, tí kì i șe bẹè mó

Ò ś bó o ti wí 


\author{
Awólówọ̀ Láyínká’s father \\ You will fulfill your promise \\ It is only bastards that make promise \\ and fail to fulfil the promise \\ You will fulfil your promise
}

This song is common among Yoruba people to eulogise kings, warriors and other famous people especially when such persons give their word. Such is used to spur the subject into action. As a result, they recreate the song by changing the names mentioned and replacing them with another subject to be praised. The song is a praise-song in honour of Awólọwò̀, the Premier of the region. The song reiterates the farmer's belief and confidence in the Premier of the region that he is a man of his word, who will not renege on his promises to the farmers. Through the adaptation of various Yorùbá songs in their films the scriptwriters have been able to establish the cultural expression and moral values of Yorùbá society in their films.

\title{
Myth
}

There have been attempts by scholars to define myth. Reader (1995) sees myth as a traditional story that articulates individual and collective apprehensions and disseminates social values. Kirk (1970) opines that myth is a traditional story which has profundity and elements of imagination as part of its hallmark. Friedlander (1996) defines myth as truth interwoven with fiction insolubly. Harris and Platzer (1996) in their own opinion consider myth as a story involving gods and heroes. What can be deduced from the definitions of the scholars is that myths are stories from ancient times about people, places and events that may or may not be true.

The Yorùbá people have rich oral traditions which form the basis of their literary heritage. Myth as an oral prose narrative constitutes a significant aspect of the Yorùbá oral tradition which provides vital background for scriptwriters of Yorùbá home-video films. Myth is known as ìtàn in Yorùbá, and there are many types of stories. İtàn İwásè (story of ancient times) are stories that relate mostly to natural phenomenon, such as sky, moon, mountain, forest and animals. Itàn İsẹ̀lẹ (Historical Narratives) relate to historical events, personages, incidents and happenings that actually occurred in the past. Itàn Àló is a fictional imagination of a fairy world in which facts and figures are blurred. İtàn Àròsọ is fictional narratives. İtàn Ẹsẹ Ifá (Ifá Divination Verse) is a story about a certain character that approaches the Ifá priest for a solution to his problem. Last but not the least is İtàn İgbàanì (Legendary Story) which is about the lineage history of a particular family or personage as told orally by their progenitors or as contained in their lineage poetry.

The five selected Yorùbá video films examined here are legendary stories of five historical figures and heroes, Basọ̀un Gáà, Exúnsetán Aníwúrà, Òrànmíyàn, Sódẹkẹ́ and Amúbíẹyá, who lived and died years ago. They were heroes in their lifetimes, and they can never be forgotten by their people because of the invaluable roles they played in the development and progress of their communities. Due to distance in time, there is a fluidity of structure 
created by spontaneous changes in the process of oral transmission; therefore, the legendary story remains a myth.

The scriptwriters of the five selected Yorùbá home-video films have appropriated the resources of their oral tradition, including myth, by subjecting them through individual and creative forge into varied new and interesting forms for aesthetics.

\section{Conclusion}

The Yorùba film as audio-visual literature is one of the most educative means of building the society. This work has attempted a descriptive analysis of five Yorùbá video films which are replete with deployments and recreations of Yorùbá oral poetic genres. Findings reveal that the Yorùbá home-video script writers make artistic use of Yorùbá oral genres in their films through the creative exploitation of proverbs, songs, chants and mythical allusions. The mythical allusions in the selected films suggest that Yorùbá home-video films share apparent inter-textual links with Yorùbá oral poetry. This study also established that Yorùbá home-video scriptwriters deploy oral poetic genres in their films to resonate the artistic experiences of the African people. The employment of the rich Yorùbá oral poetic genre by the scriptwriters also makes the films unique and often startling. In this era of crippling globalization and technological discoveries which are down-playing the cultural and linguistic heritages of the people, there is a need to recreate the Yorùbá oral tradition for dynamic aesthetic and didactic purposes. To be globally competitive, one needs to be locally useful and relevant first, which means that a sizeable dose of indigenous knowledge, values and skill is paramount. With the scriptwriters recreation of Yorùbá oral poetic genre in their films they have been able to initiate continuity and change in the use of Yorùbá oral poetic genres. This study therefore concludes that Yorùbá film-scriptwriters and their collaborators should continue to make use of oral traditions to enhance the current narrative, and balance development that would meet the needs of contemporary and future generations while simultaneously entertaining their audience. This will add to the aesthetic splendour of the Yoruba oral arts and continually give it a mass appeal. These artistic creations are more prominent in Yoruba proverbs, songs and myths to suit the contemporary world.

\section{References}

Adágbádá, O. "Womenfolk in Yorùbá video film industry”. Unpublished Ph.D Thesis University of Ibàdàn, İbàdàn (Nigeria). 2005.

Adágbádá, O. "Yoruba Texts on the Screen in Africa through the Eye of the Video. Swaziland: Academic Publishers, pp182-197. 2008.

Adédèjì, J.A. "Oral Tradition and the Contemporary Theatre in Nigeria". Research in

African Literatures. 1971.

Adélékè, D.A. “Audience Reception of Yorùbá Films:Ìbàdàn as a Case Study”. Unpublished

Ph.D Thesis, University of Ìbàdàn, Ìbàdàn. (Nigeria) 1995.

Adéòtí. G. "Home Video Films and the Democratic Imperative in Contemporary Nigeria".

Journal of African Cinemas1, no 1, 35-56. 2009. 
Adésọkàan, A. "How They See It: The Politics and Aesthetics of Nigerian Video Films" in

African Drama and Performance, edited by John Conteh-Morgan and Tejumola Olaniyan, 189-197. Bloomington: Indiana University Press. 2004.

Adú, O.T. "Propagandistic issues in Yorùbá Video Films". Unpublished M.A Project, University of İbàdàn (Nigeria). 2009.

Akínyęmí, A. "Oral Literature, Aesthetics, Transfer and Social Vision in Two Yoruba Video, Films" Research in African Literatures 38, no 3, 122-135. 2007.

Àlàmú, O.O. "Trends in the Development of Yorùbá Film: The First Decade (1976-1986)", Unpublished M.Phil Dissertation. University ofìbàdàn, İbàdàn 1991.

Àlàmú, O.O. The Aesthetics of the Yorùbá Video Films. Research Institute for World Languages. Japan. 2010.

Àlàmú, O.O. Documenting the Yorùbá Traditional Religious Festival for Posterity. Issues and Challenges. Lasu Journal of African Studies. 15. 2012.

Armes, R. "African Filmmaking: North and South of the Sahara. Bloomington: Indiana, University Press. 2006.

Arúlógun, A. "The Role of the Film in Cultural Identity in Opubor and Muneh (eds) The Development and Growth in the Film Industry in Nigeria, Lagos: National Council for Arts and Culture. 2009.

Balseiro, I. and Ntongela, M. "To Change Reels: Film and Film Culture in South Africa. Detroit:Wayne State University Press. 2003.

Barber, K. Why do we need Sociology of Literature? University of Ifẹ̀ Seminar Paper. (Nigeria) 1978.

Barber, K. "I could speak Until Tomorrow. Oríkì, Women and the Past in a Yorùbá Town". Edinburgh: Edinburgh University Press. 1991.

Dasylva, A.O." The Beauty of the Ugly: A Perspective on Albert Carous and the Absurd" in Obitun Journal of Humanity Vol.1 No.1 pp 81-90. (Nigeria) 1995.

Dovey, L. "African Film and Literature: Adapting Violence to the Screen. New York: Columbia University Press. 2009.

Ekwasi, H. "Film in Nigeria". 2 $2^{\text {nd }}$ Jos Nigeria Film Cooperation, İbàdàn (Nigeria) 1987.

Finnegan, R. "Oral Poetry: Its Nature, Significance and Social Context". Cambridge: Cambridge University Press. (1977).

Friedlander, O "Some Remarks on Research in Classics". The Classical World. Oct-Nov vol 92/No 1. 1996.

Haris, and Platzer, Classical Mythology: Images and Insights. 1985.

Hayes, J. "Nigerian Video Films. Rev (ed). Athens: Ohio University Press. 2000.

Kirk, G.S. "Myths, Its Meaning and Functions". Cambridge University Press and University of California. 1970.

Mgbejume, O. "Film in Nigeria, Development, Problems and Promise". Kenya: Africa Media Monograph Series, No. 7. 1989.

Michols, B. "Introduction to Documentary Films. Bloomington: Indiana University Press. 2010.

Mobọ́lájí, W.A. "Parody in Selected Yorùbá Video Films". Unpublished M.A. Project University of Ibadan, Ibadan. 2011.

Mobolaji, W.A. "Ìhà tí Fágúnwà Kọ Sí Ètò Ìdájọ́ Ní Àwùjọ Yorùbá” nínú Òtun İmọ nínú İtàn Àròso D.O Fágúnwà. Lagos: The Capstone Publications. 2016.

Musikawong, S. "Working Practices in Thai Independent Film Production and Distribution. Inter Asia Cultural Studies, vol 8. 2007.

Ogundeji, P.A. and Fasehun, M. A. "İdánilẹ́kọọ̣ àti Àsọtẹ́lẹ Nínu Àsọdàsílẹ D.O Fágúnwà" nínú Òtun İmọ nínú İtàn Àròso D. O Fágúnwà. Lagos: The Capstone Publications. 2016.

Ògúnlẹ́yẹ, F. African Video Film Today. Manzani, Swaziland: Academic Publishers. 2003. 
Ògúnsínà, J.A. "The sociology of the Yorùbá Novel” Unpublished M.Phil Dissertation, University of Ibadan, Ibadan. (Nigeria) 1978.

Olátúnjí, O.O. “Features of Yorùbá Oral Poetry”. İbàdàn:University Press Ltd. 1984.

Olújìnmí, I.O. “ The Portrait of Female in the Yorùbá Video Films”. Unpublished Ph.D Thesis, University of İbàdàn, İbàdàn. (Nigeria) 2005.

Olúkojú, E.O. "The place of Chants in Yorùbá Traditional and Oral Literature" Unpublished Ph.D Thesis University of Ìbàdàn, İbàdàn. (Nigeria) 1978.

Olútúndé, C.O. "Mythological Reading of Bámilóyè’s Agbára Ńlá and Ìdé Èșù Christian Films". Unpublished M.A Project, University of İbàdàn, İbàdàn. (Nigeria) 2006.

Reader, E.D. in Pandora, ed. New Jersey Princeton University. 1995.

Sesan, O. "African Aesthetics in Yorùbá Languge Video Films. A Study of Saworoidẹ and Alápadúpẹ". Unpublished M.A Project University of İbàdàn, İbàdàn (Nigeria) 2008.

Yekeen, T. "The Use of Folklores in Yorùbá Films". Unpublished M.A Project University of Ìbàdàn, İbàdàn (Nigeria) 2009.

Yusuf, A.R. “Adébáyọ̀ Fálétí on Screen”.Unpublished M.A Project University of Ìbàdàn, İ̀àdàn (Nigeria) 2006. 